\title{
PENGARUH KEMAMPUAN APARAT DESA TERHADAP KUALITAS PENGELOLAAN KEUANGAN DESA (STUDI PADA DESA-DESA DI KECAMATAN SUWAWA KABUPATEN BONE BOLANGO)
}

\author{
Rusdi Abdulkarim \\ Program Studi Akuntansi Universitas Ichsan Gorontalo \\ Jalan. Ahmad Nadjamudin No. 17 Kota Gorontalo \\ Email : rusdiyudhani@gmail.com
}

\begin{abstract}
Abstrak
Penelitian ini bertujuan untuk mengetahui seberapa besar Pengaruh Kemampuan Aparat Desa terhadap Kualitas Pengelolaan keuangan Desa pada Desa-desa di Kecamatan Suwawa Kabupaten Bone Bolango. Dalam penelitian ini penulis memilih jenis penelitian kuantitatif, dengan menggunakan metode survei. Adapun penelitian survei adalah penelitian yang mengambil sampel dari satu populasi dan menggunakan koesioner sebagai alat pengumpulan data yang pokok dan menggunakan Path Analysis sebagai metode analisis data. Hasil penelitian menunjukkan bahwa Kemampuan Aparat Desa secara simultan berpengaruh terhadap Kualitas Pengelolaan Keuangan Desa (Y), pada Desa-desa di Kecamatan Suwawa Kabupaten Bone Bolango sebesar $0,944(94,4 \%)$, dan terdapat sebesar $0,056(5,6 \%)$ dipengaruhi oleh variabel luar yang tidak diteliti. Pendidikan $\left(\mathrm{X}_{1}\right)$ sebesar 0,223 (23,3\%), Pelatihan $\left(\mathrm{X}_{2}\right)$ sebesar 0,478 (47,8\%), Pengalaman $\left(\mathrm{X}_{3}\right)$ sebesar $0,325(32,5 \%)$ berpengaruh secara parsial terhadap Kualitas Pengelolaan keuangan Desa (Y).
\end{abstract}

Kata kunci : Kemampuan dan Kualitas Pengelolaan, Keuangan Desa

Abstract

This study aims to determine how much influence the ability of village officials on the quality of village financial management in villages in Suwawa sub-district, Bone Bolango. In this study the authors chose the type of quantitative research, using survey methods. The survey research is research that takes samples from one population and uses questionnaires as a primary data collection tool and uses Path Analysis as a data analysis method. The results showed that the ability of village officials simultaneously affected the Quality of Village Financial Management (Y), in the villages in Suwawa District Bone Bolango Regency was 0.944 (94.4\%), and there was $0.056(5.6 \%)$ influenced by external variables not examined. Education (XI) of 0.223 (23.3\%), Training (X2) of 0.478 (47.8\%), Experience (X3) of 0.325 (32.5\%) partially influenced the Quality of Village Financial Management (Y).

Keywords: Management Capability and Quality, Village Finance

\section{PENDAHULUAN}

Peraturan Pemerintah Nomor 72 Tahun 2005 tentang Desa mengatur bahwa Penyelenggaraan Urusan Pemerintah Desa didanai dari Anggaran Pendapatan dan Belanja Desa dan Bantuan Pemerintah Desa. Aturan 


\section{AkMen}

tersebut diperkuat dengan SK Menteri Dalam Negeri Nomor: 140/640SJ tanggal 22 Maret 2005 tentang Pedoman Alokasi Dana Desa dari pemerintah Kabupaten kepada Pemerintah Desa, serta Peraturan Menteri Dalam Negeri Nomor 37 tahun 2007 tentang Pedoman Pengelolaan Keuangan Desa.

Melalui Alokasi Dana Desa, desa ataupun kelurahan berpeluang untuk mengelola pembangunan, pemerintahan dan sosial kemasyarakatan desa secara otonom. Alokasi Dana Desa adalah dana yang diberikan kepada desa yang berasal dari dana perimbangan keuangan pemerintah pusat dan daerah yang diterima oleh Kabupaten/Kota. Pemberian Alokasi Dana Desa merupakan wujud dari pemenuhan hak desa untuk menyelenggarakan otonominya agar tumbuh dan berkembang mengikuti pertumbuhan dari desa itu sendiri berdasarkan keanekaragaman, partisipasi, otonomi asli, demokratisasi, pemberdayaan masyarakat dan meningkatkan peran Pemerintah Desa dalam memberikan pelayanan dan meningkatkan kesejahteraan masyarakat serta memacu percepatan pembangunan dan pertumbuhan wilayah-wilayah strategis.

Alokasi Dana Desa sangat penting guna pembiayaan pengembangan wilayah tertinggal dalam suatu sistem wilayah pengembangan. Pelaksanaan Alokasi Dana Desa ini ditujukan untuk program-program fisik dan non fisik yang berhubungan dengan indikator Perkembangan Desa, meliputi tingkat pendidikan, tingkat pendapatan masyarakat, dan tingkat kesehatan.

Desa adalah pemukiman manusia dengan populasi antara beberapa ratus hingga beberapa ribu jiwa dan berlokasi di daerah pedesaan. Secara administratif Indonesia, desa adalah pembagian wilayah administratif yang berada di bawah kecamatan dan dipimpin oleh Kepala Desa. Sebuah desa secara administratif terdiri dari beberapa kampung/dusun/banjar/jorong,UndangUndang Nomor 22 Tahun 1999 tentang Pemerintahan Daerah.

Undang-Undang No. 6 Tahun 2014, desa adalah kesatuan masyarakat hukum yang memiliki batas wilayah yang berwenang untuk mengatur dan mengurus urusan pemerintahan, kepentingan masyarakat setempat berdasarkan prakarsa masyarakat, hak asal usul, dan/atau hak tradisional yang diakui dan dihormati dalam sistem pemerintahan Negara Kesatuan Republik Indonesia.

Dengan diberlakukannya Undangundang Nomor 6 Tahun 2014 tentang Desa, maka yang menjadi perhatian adalah bagaimana selanjutnya pemerintahan desa mengelola keuangan dan mempertanggungjawabkannya, Peraturan Pemerintah Nomor 60 Tahun 2014 tentang Dana Desa yang bersumber dari APBN, Pasal 1, ayat 2 : Dana Desa adalah Dana yang bersumber dari Anggaran Pendapatan dan Belanja Negara yang diperuntukkan bagi Desa yang ditransfer melalui Anggaran Pendapatan dan Belanja Daerah Kabupaten/Kota dan digunakan untuk membiayai penyelenggaraan pemerintahan, pembangunan, pembinaan kemasyarakatan, dan pemberdayaan masyarakat. Selanjutnya dalam pasal 6 disebutkan bahwa Dana Desa tersebut ditransfer melalui APBD kabupaten/kota untuk selanjutnya ditransfer ke APB Desa.

Undang-Undang Desa No. 6 Tahun 2015 Pasal 71 Ayat 1 yang dimaksud Keuangan Desa adalah hak dan kewajiban Desa yang dapat dinilai 


\section{AkMen}

dengan uang serta segala sesuatu berupa uang dan barang yang berhubungan dengan pelaksanaan hak dan kewajiban Desa. Selanjutnya pada ayat (2)nya dinyatakan bahwa adanya hak dan kewajiban akan menimbulkan pendapatan, belanja, pembiayaan, dan pengelolaan Keuangan Desa. Pasal 93 ayat (1) menyatakan bahwa pengelolaan keuangan Desa meliputi : perencanaan, pelaksanaan, penatausahaan, pelaporan, dan pertanggungjawaban. Berdasarkan pasal 105 dinyatakan ketentuan mengenai pengelolaan keuangan Desa akan diatur dalam Peraturan Menteri (Menteri Dalam Negeri). Kemudian pasal 94 menyatakan bahwa pengelolaan keuangan Desa dilaksanakan dalam masa 1 (satu) tahun anggaran terhitung mulai tanggal 1 Januari sampai dengan 31 Desember. Pasal 103 menyatakan bahwa Kepala Desa menyampaikan laporan realisasi pelaksanaan APBDesa kepada Bupati/Walikota setiap semester tahun berjalan. Laporan semester pertama disampaikan paling lambat pada akhir bulan Juli tahun berjalan. Sedangkan laporan semester kedua disampaikan paling lambat pada akhir Januari tahun berikutnya.

Karena dana desa yang bersumber dari APBN jumlahnya cukup besar maka diperlukan mekanisme kontrol dari masyarakat untuk mengawasi penggunaan dana desa tersebut agar dana tersebut dipergunakan sesuai dengan peruntukannya untuk meningkatkan kesejahteraan masyarakat. Pemerintahan Desa dituntut menyelenggarakan pemerintahan secara transparan dan akuntabel, Badan Permusyawaratan Desa (BAMUS) yang merupakan lembaga yang mempunyai fungsi pengawasan diharapkan bisa menjalankan perannya secara sungguhsungguh terutama dalam hal penggunaan anggaran.
Undang-Undang (UU) 6/2014 tentang Desa, bahwa pengelolaan keuangan desa hingga mencapai $\mathrm{Rp} 1,4$ miliar harus dikelola dengan professional, agar tidak terjadi kesalahan dan penyimpangan yang dilakukan aparatur pemerintah desa. Karena itu, pengetahuan tentang pengelolaan keuangan desa wajib dimiliki aparatur pemerintah desa di daerah, sehingga penyelenggaraan pemerintahan desa terlaksana dengan baik dan tertib administrasi. Dengan adanya aturan tersebut, maka Pemprov terus berupaya memberikan pembinaan terhadap aparatur pemerintah desa. Caranya, dengan melakukan bimbingan teknik pengelolaan keuangan daerah bagi aparatur pemerintah desa. Dengan demikian, pengelolaan keuangan desa dapat dijalankan dengan baik dan tertib administrasi.

Sebagaimana yang diamanatkan oleh undang-undang desa, pengelolaan keuangan desa harus dilaksanakan secara profesional dalam rangka menciptakan kemakmuran bagi masyarakat. Akan tetapi, berbagai problema muncul dan berpotensi menjadi hambatan dalam pengelolaan keuangan desa. Problema penelitian sebelumnya yakni penelitian Siti Nurjannah Saleba,2014 (Beberapa permasalahan dalam laporan keuangan pemerintah daerah yang memberikan dampak terhadap rendahnya kualitas laporan keuangan dikarenakan pemerintah daerah masih belum melakukan pengelolaan serta pertanggungjawaban keuangannya dengan baik, maka dari itu diperlukan posisi pengelola keuangan yang berkompeten di bidang keuangan. lain :
Problema pada penelitian antara 


\section{AkMen}

a. Kurangnya kompetensi sumber daya manusia. Dalam pengelolaan keuangan desa, dibutuhkan pengetahuan dan kemampuan yang mencukupi agar pelaksanaan pengelolaan keuangan desa dapat berjalan dengan optimal. Terlebih lagi, proses pengelolaan keuangan yang rumit membutuhkan keahlian yang mumpuni dari pemerintah desa dan Bamus serta unsur lain dalam masyarakat yang terlibat.

b. Potensi terjadinya korupsi dan kecurangan (fraud). Pengelolaan keuangan desa melibatkan dana yang relatif besar. Hal ini tentu dapat menimbulkan potensi terjadinya berbagai kecurangan dan tindak korupsi oleh berbagai pihak dalam pengelolaan keuangan desa. Apalagi jika berkaca pada berbagai kasus korupsi di level pemerintah pusat dan daerah, dimana kekuasaan telah menjadikan banyak kepala daerah, menteri, dan pejabat negara/daerah tersangkut praktik korupsi dan gratifikasi.

c. Problema terkait penyusunan dan penetapan APBDesa. Pengelolaan keuangan desa didasarkan atas APBDesa yang mencerminkan alokasi pendapatan dan pengeluaran selama satu tahun. APBDesa merupakan unsur pokok dalam pengelolaan keuangan desa. Akan tetapi, berbagai masalah muncul dalam penyusunan dan penetapan APBDesa.

Dalam kaitannya dengan kualitas sumber daya pengelolaan dan desa tersebut di atas, pemerintah pusat memfasilitasi masalah sumber daya manusia dengan membuat regulasi yang memungkinkan adanya pendampingan desa dalam pelaksanaan pemerintahan desa. Pendampingan desa adalah kegiatan untuk melakukan tinda kan pemberdayaan masyarakat melalui asist ensi, pengorganisasian,pengarahan dan fasilitasi desa (Permendesa Nomor 3 tahun 2015). Salah satu tujuan dari pendampingan desa adalah untuk meningkatkan kapasitas, efektivitas, dan akuntabilitas pemerintahan desa dan pembangunan desa. Pendampingan dilakukan oleh tiga jenis pendamping, yaitu :

a. Tenaga pendamping profesional, meliputi pendamping desa, pendamping teknis, dan tenaga ahli pemberdayaan masyarakat.

b. Kader pemberdayaan masyarakat desa, dan/atau

c. Pihak ketiga, terdiri dari lembaga swadaya masyarakat, perguruan tinggi, organisasi kemasyarakatan, atau perusahaan.

Peraturan Menteri Dalam Negeri

(Permendagri No. 113 Tahun 2014) Keuangan Desa dikelola berdasarkan asas-asas, yaitu:

1. Transparan, terbuka - keterbukaan, dalam arti segala kegiatan dan informasi terkait Pengelolaan Keuangan Desa dapat diketahui dan diawasi oleh pihak lain yang berwenang. Tidak ada sesuatu hal yang ditutup-tutupi (disembunyikan) atau dirahasiakan. Hal itu menuntut kejelasan siapa, berbuat apa serta bagaimana melaksanakannya. Transparan dalam pengelolaan keuangan mempunyai pengertian bahwa informasi keuangan diberikan secara terbuka dan jujur kepada masyarakat guna memenuhi hak masyarakat untuk mengetahui secara terbuka dan menyeluruh atas pertanggungjawaban pemerintah 


\section{AkMen}

dalam pengelolaan sumber daya yang dipercayakan kepadanya dan ketaatannya pada peraturan perundang-undangan $\quad(\mathrm{KK}$, SAP, 2005).

2. Akuntabel, Mempunyai pengertian bahwa setiap tindakan atau kinerja pemerintah/lembaga dapat dipertanggungjawabkan kepada pihak-pihak yang memiliki hak atau berkewenangan untuk meminta keterangan akan pertanggungjawaban (LAN, 2003). Dengan denikian, pelaksanaan kegiatan dan penggunaan anggaran harus dapat dipertanggungjawabkan dengan baik, mulai dari proses perencanaan hingga pertanggungjawaban.

3. Partisipatif, Mempunyai pengertian bahwa setiap tindakan dilakukan dengan mengikutsertakan keterlibatan masyarakat baik secara langsung maupun tidak langsung melalui lembaga perwakilan yang dapat menyalurkan aspirasinya.

4. Tertib dan Disiplin Anggaran, Mempunyai pengertian bahwa anggaran harus dilaksanakan secara konsisten dengan pencatatan atas penggunaannya sesuai dengan prinsip akuntansi keuangan di desa.

Kapasitas Aparatur Desa sebagai pelaksana kebijakan menjadi faktor penunjang keberhasilan pelaksanaan program-program yang dibiayai Alokasi Dana Desa (ADD). Kemampuan dan keterampilan Aparatur Desa sebagai pelaksana kebijakan merupakan dasar dari Pelaksanaan Pemerintahan khususnya di Bidang Keuangan dalam mengelola Alokasi Dana Desa.

Warisno (2009) dalam rangka pengelolaan keuangan daerah yang baik, SKPD harus memiliki sumber daya manusia yang didukung dengan latar belakang pendidikan akuntansi, sering mengikuti pendidikan dan pelatihan, dan mempunyai pengalaman di bidang keuangan karena permasalahannya adalah untuk menerapkan akuntansi double entry berbasis akrual diperlukan sumber daya manusia yang memahami logika akuntansi secara baik.

Kompetensi sumber daya manusia dalam diri pelaksana kebijakan Alokasi Dana Desa (ADD) khususnya di bidang teknis dirasa kurang memadai berdasarkan survey awal yang penulis lakukan di Desa-Desa peneriman Alokasi Dana Desa Kecamatan Suwawa, Kabupaten Bone Bolango. Kondisi ini berdampak pada kurangnya efektivitas pelaksanaan program akibat perlunya pembinaan terus menerus yang cukup menyita waktu yang dialokasikan.

Disisi lain permasalahan yang muncul adalah kurang tepatnya pencapaian sasaran program. Artinya program-program yang semula dianggarkan untuk dibiayai seringkali digantikan oleh program lain yang ternyata memiliki kepentingan yang lebih besar untuk diprioritaskan. Kondisi ini menggambarkan adanya mekanisme penyusunan penganggaran yang kurang matang sehingga terjadi kesalahan dalam penentuan prioritas pendanaan pada tahap awal. Indikasi awal yang menjadi dasar ketidaktepatan penentuan skala prioritas tersebut terletak pada kurangnya sosialisasi tentang kebijakan Alokasi Dana Desa sehingga kurang menyentuh pada masyarakat yang merupakan pelaksana langsung berbagai program yang didanai. Kurangnya sosialisasi berdampak pada kurangnya partisipasi masyarakat untuk memberikan usulan tentang program-program apa saja yang mendesak untuk dikedepankan guna didanai melalui Alokasi Dana 


\section{AkMen}

Desa.

Berkaitan dengan kebijakan dana desa, Badan Pemeriksa Keuangan (BPK) menyebutkan adanya permasalahan dalam pengelolaan keuangan desa yang bersumber dari minimnya pengetahuan perangkat desa dalam tata kelola dan pelaporan keuangan sehingga berpotensi terjadi penyelewengan/korupsi. Di kalangan DPR, muncul kekhawatiran potensi penyalahgunaan anggaran dana desa untuk kepentingan politik, khususnya saat pelaksanaan pemilihan kepala daerah (Media Akuntansi, 2014).

Beberapa penelitian tentang kemampuan sumber daya manusia yang dikaitkan dengan kualitas pengelolaan keuangan seperti Mukhlisul Muzahid (2014). Hasil penelitian menunjukan bahwa Tingkat pendidikan, kualitas pelatihan dan Pengalaman baik secara simultan maupun secara parsial berpengaruh positif dan signifikan terhadap Kualitas laporan keuangan. Perbedaan dengan penelitian adalah metode analisis data, Mukhlisul Muzahid menggunakan regresi berganda sementara penelitian ini menggunakan Struktur Jalur (path Analysis). Penelitian Ruri Widiastuti (2013). Hasil penelitian menunjukan bahwa baik secara simultan maupun parsial Sumber Daya Manusia Bidang Akuntansi dan Sistem Pengendalian berpengaruh terhadap kualitas laporan keuangan. Kemudian Mikhamad Kasanudin (2014) menemukan bahwa Kualitas Sumber Daya Manusia Pengelola dapat mempengaruhi kinerja keuangan koperasi.

Pengelolaan keuangan Desa dilakukan dengan mekanisme penganggaran ditingkat desa melalui Anggaran Pendapatan dan Belanja Desa, yang terdiri atas bagian pendapatan, belanja, dan pembiayaan Desa.
Rancangan Anggaran Pendapatan dan Belanja Desa diajukan oleh Kepala Desa dan dimusyawarahkan bersama Badan Permusyawaratan Desa. Sesuai hasil musyawarah tersebut, maka Kepala Desa menetapkan Anggaran Pendapatan dan Belanja Desa setiap tahun dengan Peraturan Desa.

Pengawasan pengelolaan keuangan desa dilakukan secara internal dan eksternal. Secara internal, pengawasan pengelolaan keuangan Desa dilakukan oleh Badan Permusyawaratan Desa. Secara eksternal pembinaan dan pengawasan pengelolaan keuangan desa dilaksanakan oleh Pemerintah Kabupaten/Kota. Hal ini ditegaskan dalam Pasal 115 huruf g UU No. 6/2014. Pengaturan pengelolaan keuangan desa dalam UU No.6/2014 menyisakan sejumlah pertanyaan kritis mengenai tata cara proses penyusunan, pembahasan, pengesahan, pelaksanaan, pengawasan serta pertanggungjawaban terkait pengelolaan keuangan desa.

Undang-Undang Desa No. 6 Tahun 2015 yang dimaksud Keuangan Desa adalah hak dan kewajiban Desa yang dapat dinilai dengan uang serta segala sesuatu berupa uang dan barang yang berhubungan dengan pelaksanaan hak dan kewajiban Desa. Selanjutnya pada ayat (2)nya dinyatakan bahwa adanya hak dan kewajiban akan menimbulkan pendapatan, belanja, pembiayaan, dan pengelolaan Keuangan Desa. Di dalam Pasal 93 ayat (1) menyatakan bahwa pengelolaan keuangan Desa meliputi :

1. Perencanaan, Secara umum, perencanaan keuangan adalah kegiatan untuk memperkirakan pendapatan dan belanja dalam kurun waktu tertentu di masa yang akan datang. Perencanaan keuangan desa dilakukan setelah tersusunnya RPJM Desa dan RKP Desa yang menjadi 


\section{AkMen}

dasar untuk menyusun APB Desa yang merupakan hasil dari perencanaan keuangan desa.

2. Pelaksanaan, Pelaksanaan dalam pengelolaan keuangan desa merupakan implementasi atau eksekusi dari Anggaran Pendapatan dan Belanja Desa. Termasuk dalam pelaksanaan diantaranya adalah proses pengadaan barang dan jasa serta proses pembayaran.

3. Penatausahaan, Penatausahaan merupakan rangkaian kegiatan yang dilakukan secara sistematis (teratur dan masuk akal/logis) dalam bidang keuangan berdasarkan prinsip, standar, serta prosedur tertentu sehingga informasi aktual (informasi yang sesungguhnya) berkenaan dengan keuangan dapat segera diperoleh.

6.

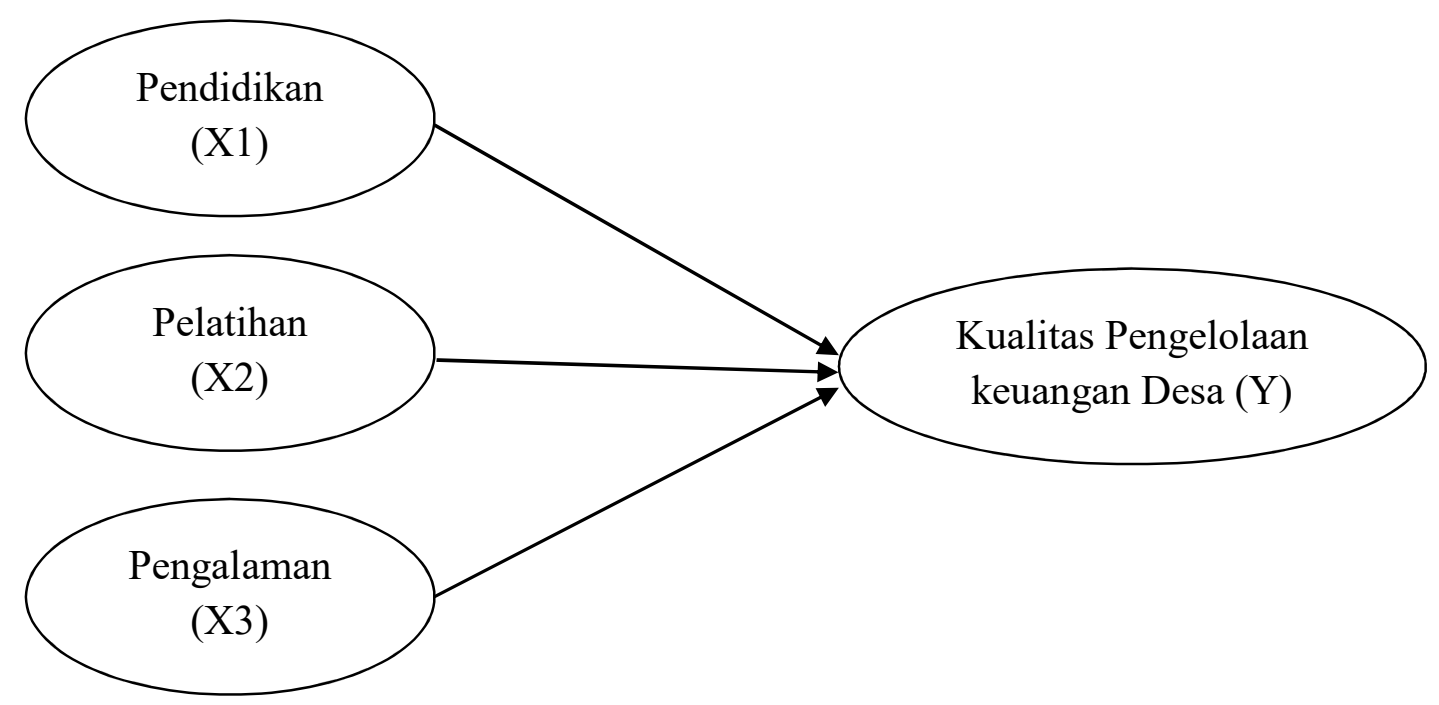

Gambar 1. Kerangka Konseptual

Berdasarkan rumusan masalah yang telah dijelaskan diatas, maka dapat ditarik jawaban sementara adalah sebagai berikut :

$$
\begin{aligned}
& \text { 1. Pendidikan berpengaruh } \\
& \text { positif dan signifikan }
\end{aligned}
$$

4. Pelaporan, Pelaporan adalah kegiatan yang dilakukan untuk menyampaikan hal-hal yang berhubungan dengan hasil pekerjaan yang telah dilakukan selama satu periode tertentu sebagai bentuk pelaksanaan tanggungjawab (pertanggungjawaban) atas tugas dan wewenang yang diberikan Laporan merupakan suatu bentuk penyajian data dan informasi mengenai sesuatu kegiatan ataupun keadaan yang berkenaan dengan adanya suatu tanggung jawab yang ditugaskan.

5. Pertanggungjawaban,

Pertanggungjawaban pengelolaan keuangan desa dilakukan setiap akhir tahun anggaran yang disampaikan kepada Bupati/Walikota dan di dalam Forum Musyawarah Desa. 


\section{AkMen}

3. Pengalaman berpengaruh positif dan signifikan terhadap kualitas pengelolaan keuangan desa.

\section{METODE PENELITIAN}

Pendekatan dalam penelitian ini adalah pendekatan kuantitatif. Populasi dalam penelitian ini adalah seluruh aparat desa sekecamatan Suwawa Kabupaten Bone Bolango yang sejumlah 70 orang. Dalam penelitian ini penarikan sampel menggunakan metode sensus yakni menjadikan seluruh populasi sebagai sampel karena jumlah populasi yang kurang dari 100 (Riduwan, 2007). Variabel penelitian Warisno (2009) terdiri dari (X1) Pendidikan merupakan fakta, informasi, dan keahlian yang diperoleh seseorang melalui pendidikan formal dengan indikator pendidikan umum dan Pendidkan Khusus. Variabel (X2) Pelatihan adalah suatu usaha untuk meningkatkan kemampuan teknis, teoritis, keterampilan, dan moral karyawan sesuai dengan kebutuhan pekerja/jabatan. Dengan indikator materi pelatihan dan metode pelatihan. dan variabel (X3) Pengalaman kerja seseorang menunjukkan jenis-jenis pekerjaan yang telah dilakukan seseorang dan memberi peluang besar bagi seseorang untuk melakukan pekerjaan yang lebih baik. Dengan indikator Lama Bekerja, Banyak Penugasan, dan Banyaknya Jenis Penugasan. Kemudian variabel $\mathrm{Y}$ yakni Pengelolaan keuangan Desa dilakukan dengan mekanisme penganggaran ditingkat desa melalui Anggaran Pendapatan dan Belanja Desa, yang terdiri atas bagian pendapatan, belanja, dan pembiayaan Desa. Undang-Undang Desa No. 6 Tahun 2015, dengan dimensi Perencanaan, Pelaksanaan, Penatausahaan, Pelaporan, dan Pertanggungjawaban.
Seluruh Instrumen yang digunakan dalam penelitian ini akan diukur dengan menggunakan Skala Likert. dalam penelitian ini terlebih dahulu akan dilakukan tahapan uji validitas dan uji reliabilitas. Selanjutnya dilakukan uji asumsi klasik (uji multikolinearitas, uji heterokedastisitas). Selanjutnya dilakukan analisis Struktur Jalur (Path Analysys) untuk menganalisis pengaruh antara beberapa variabel independen (X) dengan variabel dependen (Y). Dalam penelitian ini variabel independen yaitu Pendidikan (X1), Pelatihan (X2), dan Pengalaman (X3) dan variabel dependennya yaitu Kualitas Pengelolaan Keuangan Desa (Y).

Persamaan matematis Struktur Jalur (Path Analysis adalah sebagai berikut :

$$
\mathrm{Y}=\mathrm{PYX} 1+\mathrm{PYX} 2+\mathrm{PYX} 3+\mathrm{Py} \varepsilon
$$

\section{Selanjutnya pengujian hipotesis} Uji $F$ untuk menguji signifikansi pengaruh variabel independen terhadap variabel dependen, dan Uji $\mathrm{T}$ untuk mengetahui apakah masing-masing variabel independen mempunyai pengaruh yang terhadap variabel dependen dengan bantuan program SPSS. Metode analisis data menggunakan statistik deskriptif, uji regresi berganda, asumsi klasik (Uji Multikolonieritas, Uji Normalitas Data, Uji Heteroskedastisitas) dan uji hipotesis (Koefisien Determinanasi, Uji F dan Uji $\mathrm{T}$ dan seluruh Variabel dalam penelitian ini akan diukur dengan skala likert lima point dari sangat tidak setuju (1), tidak setuju (2), kurang setuju (3), setuju (4) dan sangat setuju (5), (Ghozali, Imam. 2006).

\section{HASIL DAN PEMBAHASAN}

Pengujian instrument penelitian ini baik dari segi validitasnya maupun reliabilitasnya terhadap 70 responden. 


\section{AkMen}

Untuk uji validitas digunakan kriteria nilai $\mathrm{t}$ hitung $>\mathrm{t}$ tabel maka dikatakan valid (Sugiyono 2012) dan untuk uji reliabilitas adalah reliabel jika nilai Alpha Crombach > 0.60 (Ghozali, 2005:46). Setelah dilakukan pengolahan data, hasil analisis data menunjukkan bahwa seluruh instrument yang digunakan dalam penelitian ini dinyatakan valid dan reliable.

Hasil uji $F_{\text {hitung }}$ menunjukkan hasil sebesar 370,868 sedangkan $\mathrm{F}_{\text {tabel }}$ sebesar 2,35 dengan taraf signifikansi adalah 0,000 . Berdasarkan uji $\mathrm{F}$ tersebut menunjukkan bahwa $\mathrm{F}_{\text {hitung }}>\mathrm{F}_{\text {tabel }}$ $(370,868>2,40)$ dan tingkat signifikansi $<\alpha=0,05$. Ini berarti bahwa pada tingkat kepercayaan 95\%, secara statistik variabel Kemampuan aparat desa yang meliputi pendidikan (X1), pelatihan (X2) dan Pengalaman (X3) secara simultan (bersama-sama) berpengaruh positif dan signifikan terhadap Kualitas Pengelolaan

Tabel 1. Hasil Struktur Jalur (path Analysis)

\begin{tabular}{|c|c|c|c|l|l|}
\hline $\begin{array}{l}\text { Hubungan antar } \\
\text { variavel }\end{array}$ & $\begin{array}{c}\text { Besarnya } \\
\text { pengaruh }\end{array}$ & $\begin{array}{c}\text { Nilai } \\
\text { sig }\end{array}$ & $\begin{array}{c}\text { Alpha } \\
(\alpha)\end{array}$ & Keputusan & Kesimpulan \\
\hline $\mathrm{Y} \leftarrow \mathrm{X}_{1}, \mathrm{X}_{2}, \mathrm{X}_{3}$ & 0,944 & 0,000 & 0,05 & Signifikan & Diterima \\
\hline $\mathrm{Y} \leftarrow \mathrm{X}_{1}$ & 0,233 & 0,000 & 0,05 & Signifikan & Diterima \\
\hline $\mathrm{Y} \leftarrow \mathrm{X}_{2}$ & 0,478 & 0,000 & 0,05 & Signifikan & Diterima \\
\hline $\mathrm{Y} \leftarrow \mathrm{X}_{3}$ & 0,325 & 0,000 & 0,05 & Signifikan & Diterima \\
\hline
\end{tabular}

Sumber : Data dioleh 2019

Dari tabel 1, dapat diketahui bahwa Kualitas pengelolaan keuangan desa dapat dijelaskan oleh variasi variabel Kemampuan Aparat Desa yang terdiri dari Pendidikan, Pelatihan dan Pengalaman secara simultan berpengaruh signifikan terhadap variabel Kualitas pengelolaan keuangan desa pada Desa di Kecamatan Suwawa Kabupaten Bone Bolango sebesar 0,944 (94,4\%); variabel Pendidikan (X1) secara parsial berpengaruh signifikan terhadap variabel Kualitas pengelolaan keuangan desa pada Desa di Kecamatan
Keuangan Desa. Hal ini berarti hipotesis yang diajukan, diterima.

Uji t dapat dilihat pada tingkat kepercayaan sebesar 95\% secara statistik menunjukan Kemampuan aparat desa yang meliputi Pendidikan,Pelatihan dan pengalaman mempunyai pengaruh yang signifikan terhadap Kualitas Pengelolaan Keuangan Desa dengan taraf signifikan $0,000<\alpha=0,05$, berarti, hal ini sesuai dengan hipotesis yang diajukan. Jadi hipotesis yang menyatakan bahwa Kemampuan aparat desa yang meliputi Pendidikan (X1) berpengaruh signifikan secara parsial terhadap Kualitas Pengelolaan Keuangan Desa pada DesaDesa di Kecamatan Suwawa Kabupaten Bone Bolango, Diterima.

Hasil pengujian hipotesis dan besarnya pengaruh variabel bebas terhadap variabel terikat uji dapat di lihat pada tabel berikut: 


\section{AkMen}

Dengan demikian dari hasil statistik, dapat disimpulkan bahwa pada hipotesis yang diajukan pada tingkat pengujian signifikan 0,05 dapat diterima (terbukti). Dari hasil estimasi pengujian hipotesis dan besarnya pengaruh variabel Pendidikan, Pelatihan dan Pengalaman terhadap variabel Kualitas pengelolaan Keuangan Desa, maka dapat dibentuk persamaan fungsional dalam model simultan sebagai berikut :

Tabel 2. Dekomposisi pengaruh varibel independen terhadap varibel dependen

\begin{tabular}{|l|c|c|c|}
\hline \multicolumn{1}{|c|}{ Keterangan } & $\begin{array}{c}\text { Pengaruh } \\
\text { langsung }\end{array}$ & $\begin{array}{c}\text { Pengaruh } \\
\text { langsung }\end{array}$ & Total \\
\hline X1 Terhadap Y & 0,233 & $23,3 \%$ & \\
\hline X2 Terhadap Y & 0,478 & $47,8 \%$ & \\
\hline X3 Terhadap Y & 0,325 & $32,5 \%$ & \\
\hline Pengaruh Varibael X1,X2,X3 Terhadap Y & & & $97,2 \%$ \\
\hline Pengaruh Varibael luar Terhadap Y & & & $2,8 \%$ \\
\hline Total & & & $100 \%$ \\
\hline
\end{tabular}

Sumber : Data diolah 2019

Dari persamaan regresi linier berganda sebagaimana tampilan table 2 , dapat dijelaskan hubungan antar setiap variabel. Variabel Pendidikan (X1) memiliki koefisien pengaruh positif terhadap Kualitas pengelolaan Keuangan Desa (Y) sebesar 0,233 artinya jika Variabel Pendidikan ditingkatkan sebesar satu satuan, maka di ikuti dengan kenaikan Kualitas pengelolaan Keuangan Desa (Y) sebesar 23,3\%. Variabel Pelatihan (X2) memiliki koefisien pengaruh positif terhadap Kualitas pengelolaan Keuangan Desa (Y) sebesar 0,478 artinya jika Pelatihan ditingkatkan sebesar satu satuan, maka di ikuti dengan kenaikan Kualitas pengelolaan Keuangan Desa (Y) sebesar 47,8\%. Variabel Pengalaman (X3) memiliki koefisien pengaruh positif terhadap Kualitas pengelolaan Keuangan Desa (Y) sebesar 0,325 artinya jika Variabel Pengalaman ditingkatkan sebesar satu satuan, maka di ikuti dengan kenaikan Kualitas
Persamaan jalur :

$$
\mathrm{Y}=0,233 \mathrm{X} 1+0,478 \mathrm{X} 2+0,325 \mathrm{X} 3+0,056 \varepsilon
$$

Dengan $\mathrm{R}^{2}=0,944$

Dari persamaan regresi linier berganda, secara sistematis pengaruh variabel Pendidikan, pelatihan dan pengalaman secara simultan maupun secara parsial terhadap Kualitas Pengelolaan Keuangan Desa dapat dijelaskan pada tabel berikut: pengelolaan Keuangan Desa (Y) sebesar $32,5 \%$. Nilai $\mathrm{R}$ pada persamaan regresi linier berganda di atas sebesar 0,972 atau 97,2\% mengindikasi bahwa variasi nilai variabel Kualitas pengelolaan Keuangan Desa (Y) ditentukan oleh variasi variabel Pendidikan, Pelatihan dan Pengalaman, sedangkan $2,8 \%$ ditentukan oleh variasi variabel lain yang tidak dijelaskan dalam model.

\section{PEMBAHASAN}

Hasil pengujian hipotesis pertama (H1) menunjukan bahwa Pendidikan secara parsial berpengaruh positif dan signifikan terhadap variabel Kualitas Pengelolaan Keuangan Desa. Besarnya pengaruh ini merupakan terkecil pengaruh terhadap Kualitas Pengelolaan Keuangan Desa. Berdasar hasil uji hipotesis dan secara empiris dilapangan berdasarkan sebaran kuesioner menunjukkan bahwa Pendidikan memberikan kontribusi terhadap 


\section{AkMen}

Kualitas Pengeloaan Keuangan Desa. Seseorang yang melakukan pekerjaan sesuai dengan pengetahuan yang dimilikinya akan memberikan hasil yang lebih baik daripada mereka yang tidak memiliki pengetahuan yang cukup memadai akan tugasnya. Besarnya usaha (proksi dari variabel akuntabilitas) yang dicurahkan seseorang untuk menyelesaikan sebuah pekerjaan berbeda-beda sesuai dengan tingkat pengetahuan yang dimiliki. Tingkat pengetahuan seseorang dapat meningkatkan kualitas hasil kerja. (Sari,2007).

Pengetahuan merupakan fakta, informasi, dan keahlian yang diperoleh seseorang melalui pendidikan, baik secara teori maupun pemahaman praktis. Kompetensi dalam aspek pengetahuan merupakan pengetahuan di bidang Sistem Akuntansi yang harus dimiliki oleh seluruh apparat desa di semua tingkat atau jenjang jabatan. Perolehan pengetahuan melibatkan proses kognitif yang kompleks meliputi: persepsi, pembelajaran, komunikasi, asosiasi dan argumentasi.

Undang-Undang (UU) 6/2014 tentang Desa, bahwa pengelolaan keuangan desa hingga mencapai Rp1,4 miliar harus dikelola dengan professional, agar tidak terjadi kesalahan dan penyimpangan yang dilakukan aparatur pemerintah desa. Karena itu, pengetahuan tentang pengelolaan keuangan desa wajib dimiliki aparatur pemerintah desa di daerah, sehingga penyelenggaraan pemerintahan desa terlaksana dengan baik dan tertib administrasi. Dengan adanya aturan tersebut, maka Pemprov terus berupaya memberikan pembinaan terhadap aparatur pemerintah desa. Caranya, dengan melakukan bimbingan teknik pengelolaan keuangan daerah bagi aparatur pemerintah desa. Dengan demikian, pengelolaan keuangan desa dapat dijalankan dengan baik dan tertib administrasi.

Hasil penelitian sejalan dengan Mukhlisul Muzahid (2014), yang menemukan bahwa Tingkat pendidikan secara parsial berpengaruh positif dan signifikan terhadap Kualitas laporan keuangan. Uraian ini mengukuhkan bahwa temuan penelitian di atas memiliki dasar teoretik yang kuat. Dengan demikian hipotesis yang diajukan pada penelitian ini DITERIMA (terbukti) bahwa Pendidikan (X1) secara parsial berpengaruh terhadap Kualitas Pengeloaan Keuangan Desa.

Hasil pengujian hipotesis Kedua (H2) menunjukan bahwa Pelatihan secara parsial berpengaruh positif dan signifikan terhadap variabel Kualitas Pengelolaan Keuangan Desa. Besarnya pengaruh tersebut merupakan penentu dominan pengaruhnya terhadap Kualitas Pengelolaan Keuangan Desa. Berdasar hasil uji hipotesis dan secara empiris dilapangan berdasarkan sebaran kuesioner menunjukkan bahwa menunjukkan bahwa Pelatihan memberikan kontribusi terhadap Kualitas Pengeloaan Keuangan Desa.

Pelatihan merupakan unsur kompleks yang diberikan untuk membantu karyawan mempelajari keterampilan yang akan meningkatkan kinerja mereka di mana akan membantu perusahaan mencapai sasarannya. Pelatihan dan pengembangan sebagai bagian pendidikan yang menyangkut proses belajar untuk memperoleh dan meningkatkan keterampilan di luar system pendidikan yang berlaku dalam waktu yang relatif singkat dengan metode yang lebih mengutamakan pada praktik dari pada teori. Sementara itu keterampilan adalah meliputi pengertian physical skill, intellectual skill, social 


\section{AkMen}

skill, managerial skill, dan lain-lain. (Rahmawati,2008:117).

Pelatihan sangat penting bagi karyawan baru maupun karyawan lama. Pelatihan, secara singkat didefinisikan sebagai suatu kegiatan untuk meningkatkan kinerja saat ini dan kinerja dimasa mendatang. Walaupun pelatihan dapat membantu karyawan untuk mengerjakan pekerjaan mereka saat ini, keuntungan dari program pelatihan dapat diperoleh sepanjang kariernya dan dapat membantu peningkatan kariernya dimasa mendatang. Kegiatan pelatihan memberikan dividen kepada karyawan dan perusahaan, berupa keahlian dan keterampilan yang selanjutnya akan menjadi aset yang berharga bagi perusahaan. Melalui pelatiahan karyawan akan bertambah kemampuannya dan demikian pula bagi perusahaan, yaitu dalam rangka memenuhi tuntutan para manajer dan departemen SDM. Namun, kegiatan pelatihan bukan solusi universal yang dapat memenuhi semua kebutuhan. Rancangan tugas yang efektif, pemilihan/seleksi, penempatan dan kegiatan-kegiatan lainnya adalah juga diperlukan.mekipun begitu, kegiatan pelatihan dapat memberikan kontribusi yang berarti kalau dikerjakan secara benar.

Hasil penelitian sejalan dengan Mukhlisul Muzahid (2014), yang menemukan bahwa Pelatihan secara parsial berpengaruh positif dan signifikan terhadap Kualitas laporan keuangan. Uraian ini mengukuhkan bahwa temuan penelitian di atas memiliki dasar teoretik yang kuat. Dengan demikian hipotesis yang diajukan pada penelitian ini DITERIMA (terbukti) bahwa Pelatihan (X2) secara parsial berpengaruh terhadap Kualitas Pengeloaan Keuangan Desa.
Hasil pengujian hipotesis ketiga (H3) menunjukan bahwa Pengalaman secara parsial berpengaruh positif dan signifikan terhadap variabel Kualitas Pengelolaan Keuangan Desa. Besarnya pengaruh ini bukan merupakan penentu dominan pengaruh terhadap Kualitas Pengelolaan Keuangan Desa. Berdasar hasil uji hipotesis dan secara empiris dilapangan berdasarkan sebaran kuesioner menunjukkan bahwa menunjukkan bahwa Pengalaman memberikan kontribusi terhadap Kualitas Pengeloaan Keuangan Desa.

Semakin luas pengalaman kerja seseorang, semakin trampil seseorang dalam melakukan pekerjaan dan semakin sempurna pula pola berpikir dan sikap dalam bertindak untuk mencapai tujuan yang telah ditetapkan. Keterampilan merupakan kemampuan untuk melakukan tugas dengan baik atau lebih baik dari rata-rata. Dalam Taksonomi Bloom, keterampilan masuk dalam ranah psikomotor yang berisi perilaku-perilaku yang menekankan aspek keterampilan motoril. Pengalaman kerja seseorang menunjukkan jenisjenis pekerjaan yang telah dilakukan seseorang dan memberi peluang besar bagi seseorang untuk melakukan pekerjaan yang lebih baik.

Secara psikis, pengalaman akan membentuk pribadi seseorang, yaitu akan membuat seseorang lebih bijaksana baik dalam berpikir maupun bertindak, karena pengalaman seseorang akan merasakan posisinya saat dia dalam keadaan baik dan saat dia dalam keadaan buruk. Seseorang akan semakin berhatihati dalam bertindak ketika ia merasakan fatalnya melakukan kesalahan. Dia akan merasa senang ketika berhasil menemukan pemecahan masalah dan akan melakukan hal serupa ketika terjadi permasalahan yang sama. Dia akan puas ketika memenangkan 


\section{AkMen}

argumentasi dan akan merasa bangga ketika memperoleh imbalan hasil pekerjaannya (Bonner dan Lewis, 1990; Farhan, 2004 dalam Singgih dan Bawono, 2010).

Dian Indri Purnamasari (2005) dalam Singgih dan Bawono (2010) memberikan kesimpulan bahwa seorang karyawan yang memiliki pengalaman kerja yang tinggi akan memiliki keunggulan dalam beberapa hal diantaranya : mendeteksi kesalahan, memahami kesalahan, dan mencari penyebab munculnya kesalahan. Jadi pengalaman merupakan hal yang sangat penting bagi sebuah profesi yang membutuhkan profesionalisme yang sangat tinggi seperti akuntan publik, karena pengalaman akan mempengaruhi kualitas pekerjaan seorang.

Hasil penelitian sejalan dengan Mukhlisul Muzahid (2014), yang menemukan bahwa Pengalaman secara parsial berpengaruh positif dan signifikan terhadap Kualitas laporan keuangan. Uraian ini mengukuhkan bahwa temuan penelitian di atas memiliki dasar teoretik yang kuat. Dengan demikian hipotesis yang diajukan pada penelitian ini DITERIMA (terbukti) bahwa Pengalama (X3) secara parsial berpengaruh terhadap Kualitas Pengeloaan Keuangan Desa.

\section{KESIMPULAN DAN SARAN}

Hasil penelitian ini menemukan variable Pendidikan, Pelatihan dan Pengalaman berpengaruh positif signifikan terhadap Kualitas Pengeloaan Keuangan Desa pada Desa-desa di Kecamatan Suwawa Kabupaten Bone Bolango. Hasil penelitian ini menyarankan kepada pemerintah kecamatan Suwawa, bahwa untuk lebih meningkatkan kualitas pengelolaan keuangan maka harus lebih intens dilakukan workshop tata kelola keuangan kepada aparatur desa, karena mengingat Sumber daya pengelolaan keuangan saat ini hanya dilakukan oleh aparatur yang berkualifikasi pendidikan rata-rata SMA.

\section{REFERENSI}

Arikunto, 2001, Metodologi Penelitian, Penerbit Gramedia, Jakarta

Azhar,2007, melakukan penelitian tentang "Kompetensi SDM UKM dan Pengaruhnya Terhadap Kinerja UKM di Surabaya". Jurnal Manajemen Dan Kewirausahaan, Vol.12, No. 1, Maret 2010: 42-55.

BPKP 2015, Modul Pengelolaan Keuangan Desa

Ghozali, Imam, 2005. Aplikasi Analisis Multivariate Dengan Program SPSS, Badan Penerbit Universitas Diponegoro, Semarang.

Hasibuan, Melayu S.P. 2008. Manajemen Sumber Daya Manusia. Bumi Aksara,

Harhinto.2004. Manajemen Sumber Daya Manusia Berbasis Kompetensi (Terjemahan). Jakarta: PT. Intermasa Jelita 2013.

Hubungan

Keterampilan dan Pekerjaan Terhadap Peningkatan Pendapatan Ibu Rumah Tangga Peserta Pelatihan Eceng Gondok Usaha Kecil dan Menengah Luthfi Craft di Desa Murtigading Piring II, Sanden, Bantul.Tesis Tidak Diterbitkan.

Yogyakarta: Program Pascasarjana UNY. 
AkMen

Yogyakarta

Kusharyanti, 2003. Pengaruh Akuntabilitas terhadap Kinerja Keuangan Daerah Pada Dinas Pendapatan, Pengelolaan Keuangan dan Aset Daerah Kabupaten Pesisir Selatan

Majalah Media Akuntansi. (2014 Oktober- November). Waspadai titik kritis pengucuran dana desa dan mencetak desa melek akuntansi. Majalah Media Akuntansi, hal. 28-31

Mardisar dan Sari, 2007. Kesiapan SDM Pemerintah Menuju Tata Kelola keuangan Negara yang Akuntabel dan Transparan. Jakarta: Kaditama Revbang BPK-RI

Rahmawati,2008 Peningkatan Daya saing UKM untuk mendukung Program PEL.Makalah Seminar Peningkatan Daya Saing. Jakarta: Graha Sucofindo Peraturan Pemerintah Nomor 72 Tahun

Undang-Undang No. 6 Tahun 2014

Undang-Undang Desa No. 6 Tahun 2015

Undang-Undang Nomor 72 Tahun 2005

Undang-Undang Nomor 32 Tahun 2004

Wahjudin, Sumpeno (2011)

Perencanaan Desa Terpadu. Banda Aceh Re-inforcement Action and Development.
Volume 16 Nomor 4 Desember 2019

Hal.580-593

e-ISSN : 2621-4377 \& p-ISSN : 1829-8524

Homepage: https//e-jurnal.stiendbel-indonesiaacid/index.php/akmen

2005

Peraturan Menteri Dalam Negeri Nomor 37 tahun 2007

Peraturan Pemerintah Nomor 60 Tahun 2014

Permendesa Nomor 3 tahun 2015

Permendagri No. 113 Tahun 2014
Riduwan , 2005, Skala Pengukuran variabel-variabel Penelitian, Penerbit Alfabeta Bandung

Riduwan, dan Kuncoro, Engkos_Achmad. 2007. Cara penggunakan Dan Menggunakan Analisis Jalur, cetakan pertama. Penerbit Alfabeta Bandung.

SK Menteri Dalam Negeri Nomor: 140/640SJ tanggal 22 Maret 2005

Sutrisno, Edy. 2009. Manajemen Sumber Daya Manusia. Jakarta: Kencana

Undang-Undang Nomor 22 Tahun 1999

Widjaja, HAW. (2004) Otonomi Desa Merupakan Otonomi yang Bulat dan Utuh. Jakarta,PT. Raja Grafindo Persada

Widiyastuti. 2009. Pengaruh Ketrampilan, Pengetahuan, Kemampuan SDM Terhadap Kinerja UKM. Skripsi Tidak Diterbitkan. Yogyakarta: PGRI 